\title{
The Bibliometric Analysis of the Studies Presented at the Turkish National Otorhinolaryngology Congresses in the Period 2009-2018
}

\author{
Original Investigation Mehmet İlhan Şahin ${ }^{1}$ (D), Emrah Gülmez ${ }^{1}$ (1), Nazlım Hilal Taraf ${ }^{2}$ (D), Veli Çetinaslan ${ }^{1}$ (1), \\ Alperen Vural ${ }^{1}$ (D), Yaşar Ünlü ${ }^{1}$ (D), Özgür Yiğit ${ }^{3}$ (D) \\ ${ }^{1}$ Department of Otorhinolaryngology, Erciyes University School of Medicine, Kayseri, Turkey \\ ${ }^{2}$ Erciyes University School of Medicine, Kayseri, Turkey \\ ${ }^{3}$ Department of Otorhinolaryngology, İstanbul Training and Research Hospital, İstanbul, Turkey
}

Abstract

ORCID iDs of the authors: M.i.Ş. 0000-0002-9576-1448; E.G. 0000-0003-0587-3532; N.H.T. $0000-0002-7735-4224$ V.Ç. 0000-0003-3871-0190; A.V. 0000-0003-1969-7760; Y.Ü. 0000-0001-7363-5048; 0.Y. 0000-0003-1731-3233.

Cite this article as: Sahin Mi, Gülmez E, Tara NH, Çetinaslan V, Vural A, Ünlü Y, et al. The Bibliometric Analysis of the Studies Presented at the Turkish National Otorhinolaryngology Congresses in the Period 2009-2018. Turk Arch Otorhinolaryngol 2020; 58(2): 99-105.

\section{Corresponding Author:}

Mehmet Illhan Şahin; misahin@erciyes.edu.tr

Received Date: 01.02 .2020

Accepted Date: 06.05 .2020

Content of this journal is licensed under a Creative Commons Attribution 4.0 International License. Available online at www.turkarchotolaryngol.net
Objective: The aim of this study was to quantitatively and qualitatively analyze the abstracts presented at Turkish National Otorhinolaryngology Congresses in the years from 2009 to 2018 .

Methods: Abstracts were defined and grouped according to their field of study, design, level of evidence, number of authors, the main institution in which they were held, and whether they were uni- or multi-centric. Frequency and percentage tables were prepared.

Results: In total, 5,463 studies, of which 1,431 (26.2\%) were oral presentations and 4,032 (73.8\%) were poster presentations were reviewed. The highest number of studies was in the field of otology and in the form of oral presentations (32\%), and in the field of head and neck surgery in the form of poster presentations (37\%). Fifty-seven percent of all studies were conducted in university hospitals, and 34\% in Training and Research Hospitals. Eighty-three percent of oral presentations and $99 \%$ of poster presentations were clinical studies. The rate of experimental animal studies was $16 \%$ in oral presentations. The most commonly used design of orally presented clinical studies was descriptive (31\%), whereas prospective randomized controlled design was the least common (3\%). No study with a level 1 of evidence was found. The rate of oral papers presented with evidence levels 2, 3, 4 , and 5 among all oral presentations were $22 \%, 13 \%$, $11 \%$, and $54 \%$, respectively.

Conclusion: The findings indicated that the abstracts were satisfactory in quantity, but overall scientific quality was not sufficient. The data obtained may serve as a basis for future studies, and follow-up studies may guide individuals and institutions that steer the Turkish ENT community.

Keywords: Abstract, presentation, poster, otorhinolaryngology, congress, bibliometric

\section{Introduction}

Medical congresses are platforms for sharing current knowledge and experiences, as well as the recent findings in scientific research and the future prospects in the respective field.

Bibliometric analysis is a method that facilitates investigating the numerical and statistical relations among scientific studies $(1,2)$. Various bibliometric analysis studies in the different fields of medicine have generally focused on articles published in scientific journals (3-6). In the literature, there are also studies that have examined the studies presented in the meetings held in different branches of medicine, both in Turkey and abroad, and mainly, the publication rates of the presented studies were ex- amined (7-10). A similar method was followed in the field of otorhinolaryngology (11-16).

It goes without saying that a scientific study finds its value by being published. The peer review process not only eliminates low-quality studies, but also increases the quality of the studies through revisions before the publication (17). Furthermore, through a paper, the results of the study are announced to a larger audience, and the study has a means of receiving citations for a long time after being published. On the other hand, presentations of the results of the studies at congresses are also important because researchers have the chance to draw the attention of other researchers for discussing their recent findings and preliminary results, and to develop collaborations with them (18). 
An overall review in a chronological order of the presentations made at the congresses also shows the scientific level of research and the trends of the society in the respective field. Therefore, investigating the different aspects of the abstracts accepted for presentation at national congresses is important to evaluate the status of scientific research in a country.

The aim of this study was to quantitatively and qualitatively analyze the abstracts presented at Turkish National Otorhinolaryngology Congresses in the period from 2009 through 2018.

\section{Methods}

The abstracts presented at the Turkish National Otorhinolaryngology Congresses from 2009 through 2018 were included in the study. Compact discs containing the abstracts were scanned, and the type of presentation, year of presentation, field of study, design, level of evidence, number of authors, the main institution in which they were held and the uni- or multi-centricity were recorded.

Fields of studies were classified as: 1. Otology (including neurotology and audiology), 2. Rhinology (including allergy), 3. Head and Neck Surgery, 4. Laryngology (including phoniatrics), 5. Pediatric otorhinolaryngology, 6. Facial plastic surgery (including reconstruction), 7. Sleep disorders, and 8. General-Other topics.

Institutions were classified as: 1 . University Hospital, 2. Training and Research Hospital, 3. Other (including private and public hospitals), and 4. Foreign Institutions. Studies with researchers from more than one institution were classified based on the senior author of the paper.

Study designs were classified in 3 main groups: 1 . Clinical study, 2. Experimental animal study, and 3. In vitro study. Clinical studies were subclassified as: 1 . Systematic review and meta-analysis, 2. Prospective randomized controlled double-blind, 3. Prospective controlled, 4. Cohort (prospective), 5. Case control (retrospective), 6. Cross-sectional, 7. Descriptive (case series), and 8. Case reports.

The level of scientific evidence for clinical trials was rated 1-23-4 and 5 (1 highest, 5 lowest) according to the classification of the Center for Evidence-Based Medicine of Oxford University (19) (Table 1).

\section{Main Points}

- This study made a comprehensive analysis of the abstracts of Turkish National Otorhinolaryngology congresses in a decade for the first time in the literature.

- The results showed that especially posters were mostly composed of case reports and case series with the lowest scientific quality.

- Among the oral presentations, there are no meta-analysis studies with evidence level 1 and the numbers of prospective randomized controlled double-blind studies and in vitro studies are very low.

- In general, the quantity overcomes the scientific quality of the presentations in Turkish National Otorhinolaryngology congresses.
Table 1. Level of evidence classification by study design (19)

\begin{tabular}{l|c} 
Study Design & Level of Evidence \\
\hline Systematic review-meta analysis & 1 \\
\hline Prospective randomized controlled double blind & 2 \\
\hline Prospective controlled & 2 \\
\hline Cohort (prospective) & 3 \\
\hline Case control (retrospective) & 4 \\
\hline Cross-sectional & 5 \\
\hline Descriptive & 5 \\
\hline Case report & 5
\end{tabular}

The studies were grouped according to the number of authors as follows: number of authors $=1,2,3-5,5-10$, and more than 10 .

\section{Statistical Analysis}

Data were analyzed using MS-Excel and Stata 14.0 (StataCorp LLC, College Station, Texas, USA). Frequency and ratio (percentage) tables were prepared. The chi-square test was used for ratio comparisons between the types of presentations (poster and oral), the centers where the studies originated (university, training and research hospital, other) and the study areas. A p value of $<0.05$ was considered statistically significant.

\section{Results}

In the period from 2009 through 2018, 5,463 studies of which $1,431(26.2 \%)$ were oral and 4,032 (73.8\%) were poster presentations were presented at Turkish National Otorhinolaryngology congresses. Of the poster presentations, 3,074 (76.2\%) were printed posters and $958(23.8 \%)$ were e-posters. While the highest number of studies were presented in 2015 (728), the least number of studies were presented in 2018 (383). However, the number of oral presentations was the highest in 2018 (190), and the lowest in 2012 (84). The total number of presentations was observed to be the lowest in the 2018 congress due to the lowest number of poster presentations (193). The number of poster presentations was highest in 2015 (549). There was a sharp and gradual decrease in the number of poster presentations after 2015 (Figure 1).

The analysis of the papers based in terms of field revealed the highest number of studies to be in the field of otology in oral presentations $(32 \%)$ and in the field of head and neck surgery $(37 \%)$ in poster presentations. The lowest number of studies were in the facial plastic surgery (2\%) in oral presentations and in sleep disorders (1\%) in poster presentations (Table 2). In oral presentations, the number of studies in the field of rhinology were seen to have increased in the years 2011 through 2014, and that rhinology became the top field in which the most numbers of studies were presented in 2014, but thereafter this number declined steadily (Figure 2).

Review of the studies according to their institutions indicated that both oral and poster presentations were mostly conduct- 
Table 2. Total numbers and rates of oral and poster presentations by field of study

\begin{tabular}{|l|c|c|c|c|c|c|c|c|c|}
\hline & & & & Pediatric & Facial & $\begin{array}{c}\text { Sleep } \\
\text { ENT }\end{array}$ & Plastic & Disorders & Other \\
Otology & Rhinology & Head \& Neck & Laryngology & Total \\
\hline Oral Presentation (n, \%) & 455,32 & 301,21 & 252,18 & 110,8 & 95,7 & 35,2 & 64,4 & 119,8 & $1,431,100$ \\
\hline Poster (n, \%) & 730,18 & 698,17 & $1,505,37$ & 188,5 & 265,7 & 141,4 & 57,1 & 448,11 & $4,032,100$ \\
\hline Total (n, \%) & $1,185,22$ & 999,18 & $1,757,32$ & 298,6 & 360,7 & 176,3 & 121,2 & 567,10 & $5,463,100$ \\
\hline
\end{tabular}

Table 3. Total numbers and rates of oral and poster presentations by conducting institutions

\begin{tabular}{l|c|c|c|c|c|}
\hline & University Hospital & Training \& Research Hospital & Other & Abroad & Total \\
\hline Oral Presentation (n, \%) & 887,62 & 495,34 & 23,2 & 26,2 & $1,431,100$ \\
\hline Poster (n, \%) & $2,234,56$ & $1,367,34$ & 374,9 & 57,1 & $4,032,100$ \\
\hline Total (n, \%) & $3,121,57$ & $1,862,34$ & 397,7 & 83,2 & $5,463,100$ \\
\hline
\end{tabular}

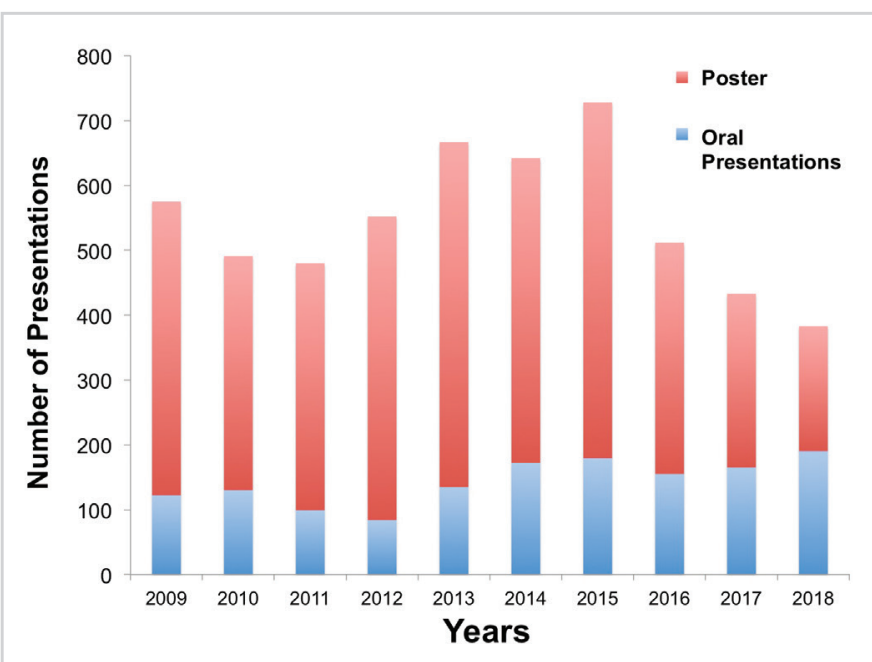

Figure 1. Yearly distribution of oral and poster presentations

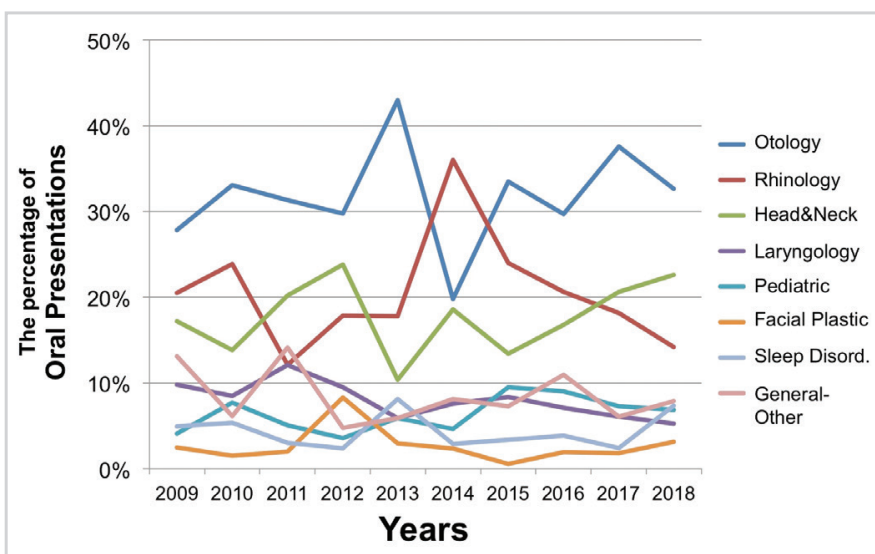

Figure 2. Yearly distribution of oral presentations according to their field of study

ed at university hospitals. In the 10 years, $57 \%$ of the studies presented as oral and poster presentations were conducted at university hospitals, 34\% at Training and Research Hospitals of the Ministry of Health, 7\% at other domestic institutions and $2 \%$ at foreign institutions (Table 3). The differences among the rates of institution types was statistically significant $(\mathrm{p}<0.001)$. Interestingly, while the ratios of University-based and Training and Research Hospital-based presentations to the total number of presentations were very close to each other in 2009 (46\%, $45 \%$, respectively), a difference had emerged gradually in favor of university hospitals over the last 10 years. In 2018, these rates were $70 \%$ and $21 \%$, respectively. The distribution of oral presentations by institutions was relatively stable. While the rate of oral presentations from universities among the total number of oral presentations was $62 \%$ in the 10 years, the rate from Training and Research Hospitals was 35\% (Figure 3).

Clinical studies were dominant among all presentations, with a rate of $83 \%$ for oral presentations and a rate of $99 \%$ for posters $(p<0.001)$. The rate of experimental animal studies was $16 \%$ for oral presentations and $1 \%$ for posters $(p<0.001)$ (Table 4$)$. Nearly half of the experimental animal studies were observed to be in otology (49.8\%), and almost half of the in vitro studies were observed to be in head and neck surgery (47.4\%). The number of in vitro studies presented in a decade was $17(1 \%)$ in oral presentations, and only $2(0 \%)$ in poster presentations. Analysis of clinical studies showed that $70 \%$ of the poster presentations consisted of case presentations and $25 \%$ of them were descriptive studies (case series). Among poster presentations, only 128 (3\%) out of a total of 3,980 clinical studies were prospective studies, 7 of which were prospective randomized controlled, 116 were non-randomized prospective controlled, and 5 were cohort studies. The majority of the clinical studies presented orally had a descriptive design (31\%), and the least commonly adopted design was the prospective randomized controlled design (3\%). Analysis of the distribution of the study designs by years showed that the rate of case presentations among all poster presentations increased steadily throughout the 10 years, from $57 \%$ in 2009 to $83 \%$ in 2018. There was no remarkable and steady change in the yearly distribution of the studies presented orally in terms of the study design (Figure 4b).

When clinical studies were reviewed according to their levels of evidence, no level 1 studies were found. The rate of levels 2, 3 
and 4 oral presentations among all oral presentations were $22 \%$, $13 \%$ and $11 \%$, respectively. Fifty-four percent of the oral presentations and $96 \%$ of the poster presentations, which consisted of case reports and cross-sectional studies, had the lowest evidence levels based on the Oxford scale used in this study. The rates of poster presentations at evidence levels 2, 3, 4, and 5 were found to be $3 \%, 0 \%, 1 \%$, and $96 \%$, respectively (Table 5 ). There was no obvious trend in terms of the level of evidence among the clinical studies presented orally in these 10 years (Figure 5).

Table 4. Total numbers and rates of presentations by design

\begin{tabular}{l|c|c|c|c}
\hline & Clinical & $\begin{array}{c}\text { Experimental } \\
\text { Animal }\end{array}$ & In vitro & Total \\
\hline $\begin{array}{l}\text { Oral Presentation } \\
\text { (n, \%) }\end{array}$ & $1,188,83$ & 226,16 & 17,1 & $1,431,100$ \\
\hline Poster (n, \%) & $3,981,99$ & 49,1 & 2,0 & $4,032,100$ \\
\hline Total (n, \%) & $5,169,95$ & 275,5 & 19,0 & $5,463,100$ \\
\hline
\end{tabular}

Most of the studies had 3-5 or 5-10 authors. The rate of oral presentations with 3-5 and 5-10 authors were $45 \%$ and $46 \%$, respectively. Sixty-three percent of the poster presentations had 3-5 authors. In both types of presentations, the rates of those with one or two authors, and those with more than 10 authors were very low (Table 6).

With regard to the number of centers involved in the presented studies, $80 \%$ of the poster presentations and $89 \%$ of the oral presentations were of single-center studies.

\section{Discussion}

The Society of Turkish Otorhinolaryngology-Head and Neck Surgery, founded in 1930, is the oldest and the most powerful professional organization of Ear Nose and Throat (ENT) specialists in Turkey (20). The Turkish National Otorhinolaryngology Congress, which was held 41 times annually since 2007, congregated for the first time in 1951 (20).

The Turkish National Otorhinolaryngology Congresses creates a rich information-sharing environment with the contributions

Table 5. Total numbers and rates of clinical studies by evidence levels

\begin{tabular}{|c|c|c|c|c|c|c|}
\hline & \multicolumn{5}{|c|}{ Level of Evidence } & \multirow[b]{2}{*}{ Total } \\
\hline & 1 & 2 & 3 & 4 & 5 & \\
\hline Oral Presentation (n, \%) & 0,0 & 260,22 & 156,13 & 131,11 & 641,54 & 1,188 \\
\hline Poster (n, \%) & 0,0 & 123,3 & 5,0 & 18,1 & $3,834,96$ & 3,980 \\
\hline Total (n, \%) & 0,0 & 383,7 & 161,3 & 149,3 & $4,475,87$ & 5,168 \\
\hline
\end{tabular}

Table 6. Total numbers and rates of presentations by number of authors

\begin{tabular}{l|c|c|c|c|c|c|}
\hline & \multicolumn{5}{|c|}{ Number of Authors } & \multicolumn{2}{c|}{ Total } \\
\cline { 2 - 7 } & $\mathbf{1}$ & $\mathbf{2}$ & $\mathbf{3 - 5}$ & $\mathbf{6 - 1 0}$ & 21,1 \\
\hline Oral Presentation (n, \%) & 45,3 & 68,5 & 637,45 & 660,46 & 1,431 \\
\hline Poster (n, \%) & 66,2 & 200,5 & $2,548,63$ & $1,213,30$ & 5,0 & 4,032 \\
\hline Total (n, \%) & 111,2 & 268,5 & $3,185,58$ & $1,873,34$ & 26,1 & 5,463 \\
\hline
\end{tabular}
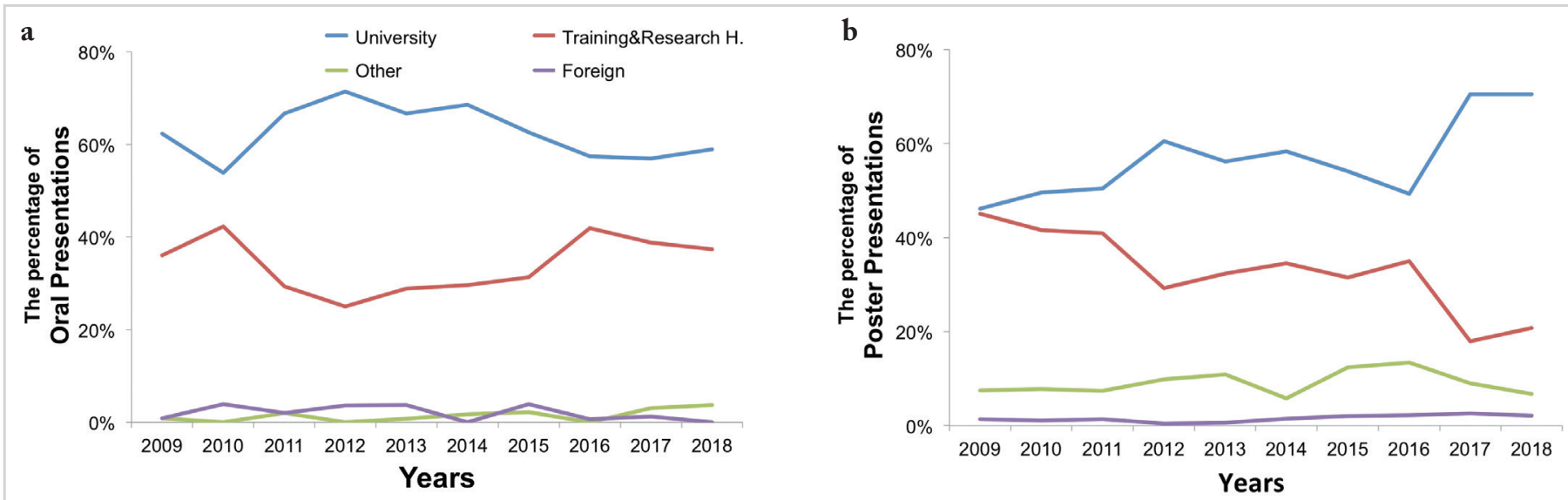

Figure 3. a, b. Yearly distribution of presentations according to the institutions they were conducted in. (a) Oral presentations. (b) Poster presentations 


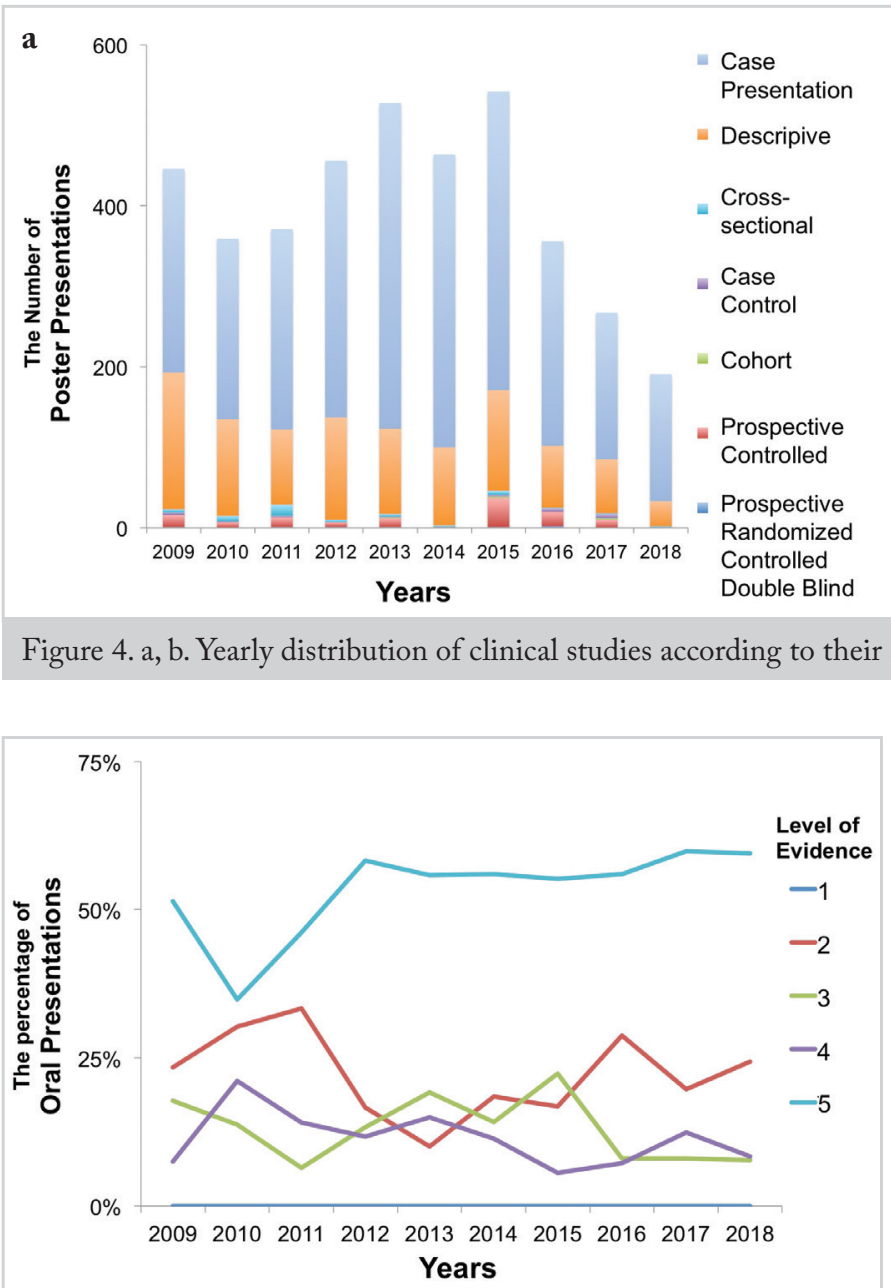

Figure 5. Yearly distribution of clinical studies presented orally according to their levels of evidence

of international speakers, as well as many local academicians, many of whom are internationally renowned. Hundreds of oral presentations and poster presentations are made at these congresses every year. The paper presentations are a means for sharing the results of current scientific studies among colleagues. Presented papers, on the other hand, can be regarded as an indicator of the scientific qualifications, strengths, and weaknesses, of the Turkish ENT community, as well as the scientific and professional inclinations of the researchers.

According to a comprehensive study examining the scientific publications between 2010 and 2015, Turkey ranks $16^{\text {th }}$ in the number of scientific publications in the medical sciences, but $26^{\text {th }}$ in the number of citations. The same study revealed that in general surgery, which is one of the most published fields, Turkey is $10^{\text {th }}$ in number, but $46^{\text {th }}$ in effect. Turkey also ranks $13^{\text {th }}$ in ophthalmology and orthopedics, while ranking $45^{\text {th }}$ and $41^{\text {th }}$, respectively, in effect (21). In addition, according to the report published by the University Ranking by Academic Performance (URAP) of the Middle East Technical University, the rate of cited publications is below the world average (22). Similarly, Koca et al. (23) found that the rates of the dissertations written by orthopedics residents from 1974 through 2014 in Turkey with evidence level 1 was $8.6 \%$ and level 2 was $5.8 \%$. Additionally,

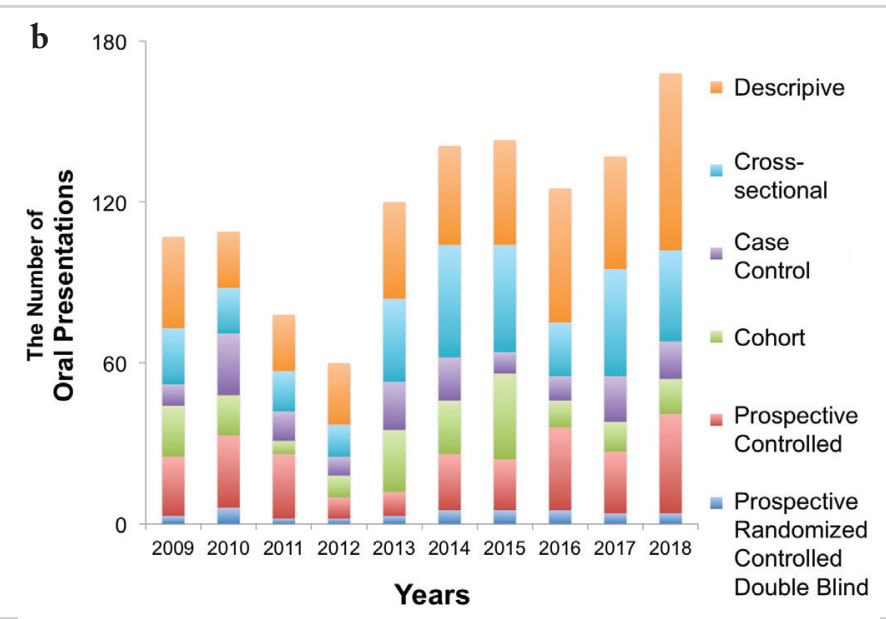

Cevik et al. (24) examined the study design of the dissertations in the emergency medicine field and reported that majority of them $(77.4 \%)$ were observational studies. However, Özgen et al. (25) analyzed the publication pattern of Turkish medical dissertations from 1980 through 2005 and found that the average number of publications that cited the published dissertations were below 1 before 1995, but increased gradually afterwards.

These reports suggest that although the impact and citations of the medical publications from Turkey have been increasing, still, the quantity exceeds the quality of medical publication productivity in our country. This situation is much more dramatic in surgical sciences. It can be predicted that the academic promotion criteria in Turkey is one of the reasons that may be forcing academicians to prioritize quantity over quality in research and publication. The same situation is deemed to be valid for the studies presented at scientific congresses.

There is a limited number of studies from Turkey analyzing the abstracts of the presentations at congresses in the different fields of medicine $(7,8,15,16)$. The focus of the majority of the domestic studies, and of the international ones as well, was the publication rates of the presented abstracts as articles (7-16). There are, however, fewer studies investigating the scientific qualifications of the abstracts other than the publication rates $(26,27)$. In one of these studies, Dossett et al. (26) reviewed the reports of the 2009 American Congress of Trauma Surgery in terms of quantity and scientific quality and found that $51 \%$ of the reports were clinical trials, and only $8 \%$ were randomized trials. Interestingly, the scientific quality of poster presentations from studies scored by blind researchers was higher than oral presentations.

In our study, the number of posters was found to be considerably higher than the number of oral presentations, albeit after 2015 the number of posters decreased rapidly. This decrease may be related to the radical changes introduced with the amendment of the academic promotion criteria in Turkey, in which poster presentations were not scored, but oral presentations became mandatory. Another outcome of the changes introduced 
with the amendment may be the decrease in the numbers of authors per submission seen in the recent years, since according to the new criteria, promotion scores are calculated by dividing the score of the oral presentation by the number of the authors involved.

The results of this study show that while universities are leading the research in the field of otorhinolaryngology in Turkey, Training and Research Hospitals of the Ministry of Health also have a considerable share. Our results are consistent with a previous study, in which Erdağ et al. (28) analyzed the papers published in four Turkish otorhinolaryngology journals from 2002 through 2010 and indicated that the number of studies from university hospitals were higher than those from other institutions. On the other hand, it is worth noting that multicentric studies have a small share.

A review of the studies presented at Turkish National Otorhinolaryngology Congresses based on study design and evidence level parameters with regards to their scientific qualifications was performed for the first time in our study. The results showed that especially posters were composed of case reports and case series reports with the lowest scientific quality. Likewise, it is striking that there are no meta-analysis studies with evidence level 1 and the numbers of in vitro studies and prospective randomized controlled double-blind studies are very low. Regretfully, in a paper which was published in 2013 (28), it was also indicated that no studies with evidence level 1 existed in Turkish otorhinolaryngology journals in 2002, 2005, and 2010. It is clear that the scientific quality and the evidence level of the studies performed by Turkish otolaryngologists need yet to be improved.

\section{Conslusion}

This study made a comprehensive analysis of the abstracts of Turkish National Otorhinolaryngology congresses in a decade for the first time in the literature. Our findings demonstrated that the abstracts were satisfactory in quantity, but their overall scientific quality was not satisfactory. The data obtained may serve as a basis for future studies, and follow-up studies may guide individuals and institutions that steer the Turkish ENT community.

Ethics Committee Approval: Ethics committee approval was not received due to the nature of this study.

Informed Consent: Informed consent was not obtained due to the nature of the study.

Peer-review: Externally peer-reviewed

Author Contributions: Concept - M.İ.Ş.; Design - M.İ.Ş., E.G., A.V.; Supervision - M.İ.Ş., Y.Ü., Ö.Y.; Materials - M.İ.Ş., E.G., Ö.Y.; Data Collection and/or Processing - M.İ.Ş., E.G., N.H.T., V.Ç.; Analysis and/or Interpretation - M.İ.Ş., E.G., N.H.T., V.Ç.; Literature Search - M.İ.Ş., E.G., N.H.T., V.Ç., A.V.; Writing - M.İ.Ş., A.V.; Critical Reviews - M.İ.Ş., A.V., Ö.Y.

Conflict of Interest: The authors have no conflicts of interest to declare.
Financial Disclosure: The authors declare that this study has received no financial support.

\section{References}

1. CABİM TÜBİTAK ULAKBİM. Bibliyometrik Analiz 2019. [Bibliometric analysis 2019]. Available from: https://cabim.ulakbim.gov.tr/bibliyometrik-analiz.

2. Ellegaard $\mathrm{O}$,Wallin JA. The bibliometric analysis of scholarly production: how great is the impact? Scientometrics 2015; 105: 1809-31. [Crossref]

3. Lu C, Bing Z, Bi Z, Liu M, Lu T, Xun Y, et al. Top-100 most cited publications concerning network pharmacology: a bibliometric analysis. Evid Based Compl Alt 2019:1704816. [Crossref]

4. Zou Y, Luo Y, Zhang J, Xia N, Tan G, Huang C. Bibliometric analysis of oncolytic virus research, 2000 to 2018. Medicine 2019; 98: e16817. [Crossref]

5. Gurbuz Y, Sugun TS, Ozaksar K. A bibliometric analysis of orthopedic publications originating from Turkey. Acta Orthop Traumatol Turc 2015; 49: 57-66. [Crossref]

6. Akyıldız İ, Kızıl Y. Evaluation of articles on rhinology published in national otorhinolaryngology journals between 2010-2015. Turk Arch Otorhinolaryngol 2015; 53:150-4. [Crossref]

7. Meral UM, Urkan M, Alakuş Ü, Lapsekili E, İflazoğlu N, Ünlü A, et al. Publication rates of abstracts presented at the annual congress of the Turkish Society of Colorectal Surgery (years 20032011). Turk J Surg 2017; 33: 87-90. [Crossref]

8. Günay S, Sariaydin M, Sarinc-Ulasli S, Günay E, Demir S, Unlu $M$. The publication rates of abstracts presented at the Turkish Respiratory Society (TUSAD) annual congress: adequate or not? Clin Respir J 2018; 12: 158-64. [Crossref]

9. Mimouni M, Krauthammer M, Abualhasan H, Badarni H, Imtanis K, Allon G, et al. Publication outcome of abstracts submitted to the American Academy of Ophthalmology meeting.J Med Libr Assoc 2018; 106: 57-64. [Crossref]

10. Janssen T, Bartels R, Lind B, Villas Tome C, Vleggeert-Lankamp $\mathrm{CL}$. Publication rate of paper and podium presentations from the European Section of the Cervical Spine Research Society Annual Meeting. Eur Spine J 2016; 25: 2311-6. [Crossref]

11. Larian B, Namazie A, Agha N, Azizzadeh B, Blackwell K, Wang MB. Publication rate of abstracts presented at the annual meeting of the American Academy of Otolaryngology-Head and Neck Surgery. Otolaryngol Head Neck Surg 2001; 125: 166-9. [Crossref]

12. Roy D, Sankar V, Hughes JP, Jones A, Fenton JE. Publication rates of scientific papers presented at the Otorhinolarygological Research Society meetings. Clin Otolaryngol 2001; 26: 253-6. [Crossref]

13. Peng PH, Wasserman JM, Rosenfeld RM. Factors influencing publication of abstracts presented at the AAO-HNS Annual Meeting. Otolaryngol Head Neck Surg 2006; 135: 197-203. [Crossref]

14. Cohen MA, Mirza N, Dow K, Abboud SK. Presentation and publication rates among women and men at AAO-HNS meetings. ORL 2012; 74: 325-9. [Crossref]

15. Doğan E, Durmuşoğlu M, Erdağ TK. Türk Ulusal Rinoloji Kongrelerinde Sunulan Bildirilerin Yayınlanma Oranları [Publication rates of presentations which were presented at Turkish National Rhinology Congresses]. Kulak Burun Bogaz Ihtis Derg 2013; 23: 282-7. [Crossref]

16. Erdağ TK, Durmuşoğlu M, Demir AO, Doğan E, İkiz AÖ. [The Analysis and Publication Rates of The Abstracts Presented at The Turkish National Otorhinolaryngology Head and Neck Surgery Congresses]. Kulak Burun Bogaz İhtis Derg 2014; 24: 89-96. [Crossref]

17. Esarey J. Does peer review identify the best papers? A simulation study of editors, reviewers, and the scientific publication process. PS Polit Sci Politics 2017; 50: 963-9. [Crossref] 
18. Dogruyol S, Avci S. Contribution of national congress presentations to scientific literature: an analysis of efficiency. Turk J Emerg Med 2019; 19: 53-7. [Crossref]

19. Oxford Centre for Evidence-Based Medicine. The Oxford 2011 Levels of Evidence. England: Oxford University; 2011. Available from: https:/www.cebm.net/wp-content/uploads/2014/06/ CEBM-Levels-of-Evidence-2.1.pdf

20. Türk KBB\&BBC Derneği. Tarihçe: Türk Kulak Burun Boğaz ve Baş Boyun Cerrahisi Derneği; 2019. Available from: https://www. kbb.org.tr/menu/tarihce-9.

21. CABİM TÜBİTAK ULAKBİM. Bilim Dallarında Dünya, Ülkeler ve Gruplara Ait Veriler:Tibbi Bilimler (2010-2015). 2016. Available from: https://cabim.ulakbim.gov.tr/bibliyometrik-anal$\mathrm{iz/turkiye-bilimsel-yayin-performans-raporlari/bilim-dallarinda-}$ dunya-ulkeler-ve-gruplara-ait-veriler-tibbi-bilimler-2010-2015raporu/.

22. University Ranking by Academic Performance (URAP). 20182019 URAP Türkiye Sıralaması. 2019. Available from: http:// tr.urapcenter.org/2019/2018-2019-URAP-Turkiye-Siralamasi-Raporu.pdf.
23. Koca K, Ekinci S, Akpancar S, Gemci MH, Erşen Ö, Akyıldız F. An analysis of orthopaedic theses in Turkey: evidence levels and publication rates. Acta Orthop Traumatol Turc 2016; 50: 562-6. [Crossref]

24. Cevik E, Yilmaz BK, Acar YA, Dokur M. Systematic analysis of theses in the field of emergency medicine in Turkey. Turk J Emerg Med 2015; 15: 28-32. [Crossref]

25. Özgen Ü, Eğri M, Aktaş M, Sandıkkaya A, Öztürk ÖF, Can S, et al. Publication pattern of Turkish medical theses: analysis of 22.625 medical theses completed in years 1980-2005. Turk Klin J Med Sci 2011; 31: 1122-31. [Crossref]

26. Dossett LA, Fox EE, del Junco DJ, Zaydfudim V, Kauffmann R, Shelton J, et al. Don't forget the posters! Quality and content variables associated with accepted abstracts at a national trauma meeting. J Trauma Acute Care Surg 2012; 72: 1429-34. [Crossref]

27. Rowe N. Tracing the 'grey literature'of poster presentations: a mapping review. Health Info Libr J 2017; 34: 106-24. [Crossref]

28. Erdağ TK, Doğan E, Ecevit MC, Durmuşoğlu M, Güneri EA, İkiz AÖ. [Quantitative and qualitative analysis of four national otorhinolaryngology journals between 2002 and 2010.] Kulak Burun Bogaz Ihtis Derg 2013; 23: 260-7. [Crossref] 